\begin{tabular}{|c|c|c|c|c|r|r|r|r|r|rr|l|}
\hline & E & $\mathbf{O}$ & $\mathbf{S}$ & & & $\mathbf{6}$ & $\mathbf{6}$ & $\mathbf{0}$ & $\mathbf{R}$ & Dispatch: 19.6.09 & Journal: E0S & CE: Manonmani \\
\cline { 1 - 3 } \\
\hline
\end{tabular}

\section{Epstein-Barr virus prevalence in oral 1squamous cell cancer and in potentially malignant oral disorders in an eastern Hungarian population}

Kis A, Fehér E, Gáll T, Tar I, Boda R, Tóth ED, Méhes G, Gergely L, Szarka K. Epstein-Barr virus prevalence in oral squamous cell cancer and in potentially malignant oral disorders in an eastern Hungarian population. Eur J Oral Sci 2009; 117: 1-5. (C) 2009 The Authors. Journal compilation (C) 2009 Eur J Oral Sci

We tested 65, 44, and 116 patients with oral squamous cell cancer (OSCC), oral leukoplakia (OL), and oral lichen planus (OLP) against 68 age-matched controls for the presence of Epstein-Barr virus (EBV). Apparently healthy mucosa was simultaneously sampled and examined in all patients. Paraffin-embedded tissue sections of all EBV-positive patients with OSCC were examined for latent membrane protein-1 (LMP-1) expression (demonstrable in most EBV-associated malignancies) using immunohistochemistry. The prevalence of EBV in the controls and in OSCC, OL, and OLP lesions was $19.1 \%, 73.8 \%, 29.5 \%$, and $46.6 \%$, respectively, and $66.2 \%, 22.7 \%$, and $31.9 \%$ in the healthy mucosa of patients, respectively. The prevalence of EBV in OSCC patients was significantly higher than in controls or in respective samples of the other two patient groups both in the lesion and in the healthy mucosa. Comparisons including only patients with EBV-negative lesions yielded similar results. Lesions of patients with OLP, but not of patients with OL, differed significantly from controls in EBV prevalence. In OSCC, LMP-1 expression was not detected, and EBV carriage was not significantly associated with any risk factors and did not influence the outcome. Although a high prevalence of EBV was found in OSCC, comparable carriage rates on healthy mucosa of patients indicated that an aetiological role of EBV is unlikely.
Andrea Kis ${ }^{1}$, Enikő Fehér ${ }^{1}$, Tamás Gáll ${ }^{1}$, Ildikó Tar $^{2}$, Róbert Boda ${ }^{2}$, Etelka D. Tóth ${ }^{2}$, Gábor Méhes ${ }^{3}$, Lajos Gergely $^{1}$, Krisztina Szarka ${ }^{1}$

${ }^{1}$ Department of Medical Microbiology, Medical and Health Science Centre, University of Debrecen, Debrecen, Hungary; ${ }^{2}$ Faculty of Dentistry, Medical and Health Science Centre, University of Debrecen, Debrecen, Hungary; ${ }^{3}$ Department of Pathology, Medical and Health Science Centre, University of Debrecen,

Debrecen, Hungary

Krisztina Szarka, PhD, Department of Medical Microbiology, Medical and Health Science Centre, University of Debrecen, $\mathrm{H}-4032$ Debrecen, Nagyerdei krt. 98, Hungary

Telefax: +36-52-417565 E-mail: szkrisz@med.unideb.hu

Key words: aetiology; oral leukoplakia; oral lichen planus; oral squamous cell cancer

Accepted for publication May 2009
Epstein-Barr virus (EBV) is a double-stranded DNA virus belonging to the Gammaherpesvirinae subfamily. Epstein-Barr virus has a lifelong persistence in the human host, where it is common and is distributed 2 worldwide in the normal population (1). The virus is ubiquitous, with a seroprevalence of between 50 and $95 \%$ (2). After primary infection, EBV establishes a latent infection in a small proportion of B lymphocytes as well as in oronasopharyngeal and salivary gland epithelial cells, periodically replicates in the oropharynx or in salivary gland epithelium, and is then shed in the saliva (3).

It is well known that EBV is associated with a variety of malignant disorders such as nasopharyngeal carcinoma (4), Burkitt's lymphoma, Hodgkin's disease, and B-cell lymphoma $(5,6)$. It is frequently associated with malignant and benign diseases of the immunocompromised (e.g. different B-cell lymphomas and oral hairy leukoplakia) (2, 5). Besides these established disease associations, a role of EBV has been presumed in many different malignant diseases, such as leiomyosarcoma, gastric adenocarcinoma, certain non-B-cell lymphomas (1), and oral squamous cell cancer (OSCC) (7), as well as in some benign and potentially malignant oral lesions and diseases, including oral lichen planus (OLP) (8), gingivitis, and periodontitis (2).

Several viral proteins have been found be involved in the transforming activity of, and in the carcinogenesis induced by, EBV; these include the latency-associated proteins latent membrane proteins 1 and 2 (LMP-1 and LMP-2) and Epstein-Barr virus nuclear antigens (EBNA1-6) (3, 5). Of these, LMP-1, EBNA-2, and EBNA-3 are indispensable for the immortalization of $B$ cells; LMP-1 was also shown to be involved in the transformation of murine fibroblasts $(3,5)$. Some of these proteins were demonstrated, by immunohistochemical analyses, to be present in EBV-associated malignant cells (5).

The prevalence of EBV in oral samples varies widely in different studies. Most south-east Asian studies found a high prevalence of EBV and concluded an aetiological role of EBV in $\operatorname{OSCC}(9,10)$; and in an Egyptian population this was also supported by immunohistochemical detection of LMP-1, the EBV antigen associated with transforming activity $(11,12)$. By contrast, North American studies, as well as West and North European 
studies, regularly report lower prevalences of EBV and conclude that the aetiological role of EBV is doubtful in OSCC (13-15).

The aim of the present study was to collect data on the prevalence of EBV DNA in patients with OSSC, OLP, and oral leukoplakia (OL) in an eastern Hungarian population with a relatively high incidence of OSCC. To track the source of EBV in these patients we also took a sample of the apparently healthy mucosa of the patients simultaneously when taking a sample of the lesion.

\section{Material and methods}

\section{Study groups, specimens, and DNA extraction}

All patients enrolled in the study attended the Department of Oral and Maxillofacial Surgery and the Department of Periodontology, Faculty of Dentistry, University of Debrecen, Hungary, during 2003-2007. Histopathological results based on targeted biopsy were available at the time of sample collection in each patient. We included OSCC patients if (i) they were newly diagnosed patients and (ii) they did not undergo neoadjuvant chemotherapy or radiotherapy before the surgical intervention and specimen collection. Similarly, we included patients with potentially malignant oral lesions if (i) they were newly diagnosed patients and (ii) they did not receive any therapy for their lesion before sampling. All individuals fulfilling the inclusion criteria and agreeing to participate were enrolled. Sixty-five patients with OSCC (51 men, 14 women; mean age $54.4 \mathrm{yr}$; age-range $25-80 \mathrm{yr}), 44$ patients with OL (14 men, 30 women; mean age $56.3 \mathrm{yr}$; age-range 29-91 yr), and 116 patients with OLP (29 men, 87 women; mean age $55.0 \mathrm{yr}$; age-range 23-79) were enrolled in the study. The age-matched control group consisted of 68 individuals without a history of oral disease or malignancy, with a healthy oral mucosa (16 men, 52 women; age-range 22-77 yr; mean age $52.5 \mathrm{yr}$ ). Control individuals were from the same geographical area as the patients (eastern Hungary) and had been referred to the Faculty of Dentistry for 3 regular oral screening. Written informed consent was 4 collected from each patient enrolled. The study was approved by the local ethics committee (approval number: 2273-2004).

Data were also collected on exposure to known risk factors of OSCC relevant in the region (smoking, alcohol consumption) and pathological characteristics [localization, tumour node metastasis (TNM) stage according to the Tumour-Node-Metastasis staging of carcinomas and histological grade of the tumour]. To assess complication-free survival (survival without recurrence, growth of new tumour or metastasis), patients were followed-up after surgical intervention; the mean follow-up time was 31 months (range: $1.5-60$ months).

As certain clinical variants of OLP (erosive and atrophic forms; EA-OLP) are more prone to malignant transformation than others (plaque-like and reticular forms; non-EA-OLP), and, similarly, there are OLs with higher (non-homogeneous OL; erythroleukoplakia and verrucous forms) and with lower (homogeneous OL) risks of malignization, potentially malignant oral lesions (OL and OLP) were divided into two respective groups according to clinical appearance associated with higher risk of malignant transformation, to subgroups EA-OLP (59 individuals: 13 men,
46 women; mean age $57.5 \mathrm{yr}$; age-range 23-79 yr) and nonEA-OLP (57 individuals: 16 men, 41 women; mean age $52.4 \mathrm{yr}$; age-range $24-75 \mathrm{yr}$ ), as well as to non-homogeneous OL (14 individuals: 5 men, 9 women; mean age $51.5 \mathrm{yr}$; range $29-71 \mathrm{yr}$ ) and homogeneous OL (30 individuals: 9 men, 21 women; mean age $58.5 \mathrm{yr}$; age-range 35-91 yr).

Excised tissue samples of patients with OSCC were obtained, during surgical intervention, from the centre of the tumour. Another part of the tissue sample was submitted for histopathological and immunohistochemical analyses (see below). In OL and OLP groups, exfoliated cells were collected from the surface of oral lesions. In all groups of patients, before specimen collection from the lesions, exfoliated cells were harvested from the apparently healthy mucosa at the farthest possible site from the lesion. Control specimens consisted of cytobrush-harvested exfoliated buccal epithelial cells collected from healthy individuals. To minimize contamination of the exfoliated cell samples with saliva, sampling was preceded by two thorough mouth rinses with physiological saline.

DNA was isolated using TRI Reagent (Sigma, St Louis, MO, USA), according to the manufacturer's recommenda5 tions for tumour tissue samples and exfoliated cells, from OSCC patients. Extraction of DNA from samples of exfoliated cells from patients with OL and OLP, and from control individuals, was performed with proteinase $\mathrm{K}$ digestion followed by treatment with $5 \mathrm{M} \mathrm{NaCl}$, and DNA was precipitated using $96 \%$ ethanol.

\section{EBV detection by polymerase chain reaction}

We used a nested polymerase chain reaction (PCR), amplifying a 97-bp region of the internal repeat of the Bam H1-W fragment of the EBV genome, constructed from two previously described overlapping PCR assays (16). Briefly, primers EBV-F (5'-GAGACCGAAGTGAAG GCCCT-3') and EBV-R (5'-ACAGCTCCTAAGAAGG CACC-3') were used to amplify a 171-bp product, and then primers EBV B-F (5'-GCCAGAGGTAAGTGGACTTT-3') and EBV B-R (5'-GAGGGGACCCTGAGACGGGT-3') were used to amplify a 97-bp fragment within the amplimer yielded by the first round of PCR. Both PCR assays were performed in a final volume of $25 \mu \mathrm{l}$ containing $250 \mu \mathrm{M}$ of each dNTP, $25 \mathrm{pmol}$ of each primer, and $0.5 \mathrm{U}$ of GoTaq DNA polymerase in $1 \times$ PCR buffer containing $\mathrm{MgCl}_{2}$ (supplied by the manufacturer; Promega, Madison, WI, USA). Thermal profiles were: $94^{\circ} \mathrm{C}$ for $5 \mathrm{~min}$; 35 cycles of $94^{\circ} \mathrm{C}$ for $30 \mathrm{~s}, 58^{\circ} \mathrm{C}$ for $30 \mathrm{~s}$, and $72^{\circ} \mathrm{C}$ for $30 \mathrm{~s}$; and a final extension at $72^{\circ} \mathrm{C}$ for $5 \mathrm{~min}$ in both rounds. DNA from the EBV-positive B95-8 cell line was used as a positive control.

\section{Detection of LMP-1 using immunohistochemistry}

Immunohistochemistry was performed with the DakoCytomation LSAB + System AP (Dako Denmark, Glostrup, Denmark), using monoclonal mouse antibodies against LMP-1, according to the manufacturer's recommendations. Two paraffin-embedded tumour-tissue sections were tested in all 48 patients with EBV-positive OSCC tumour tissue. A paraffin-embedded lymph node preparation from a patient with EBV-positive Hodgkin's disease was used as a positive control, while lymph node sections from EBV-negative Hodgkin's disease patients served as negative controls. 


\section{Statistical analysis}

Statistical comparison of prevalence data was performed using chi-square and Fisher's exact tests. Logistic regression was used to analyze the association between EBV carriage and patient characteristics (gender and age) as well as the clinical appearance of OLP. Because of the small number of 6 patients with non-homogeneous OL, the clinical appearance of OL was not analyzed statistically. The association of tumour characteristics (localization, histological grade, and TN stage) with exposure to risk factors (smoking and alcohol consumption) in patients with OSCC was also analyzed using logistic regression. Tumour-free survival of OSCC patients was analyzed using the Kaplan-Meier test. All tests were carried out with a confidence interval (CI) of 95\% using SPSS 15.0 for Windows software.

\section{Results}

\section{EBV prevalence data}

The prevalence of EBV DNA was $19.1 \%(13 / 68)$ in the control group. In patients with OSCC, OL, and OLP, the carriage rates in the lesion were $73.8 \%(48 / 65), 29.5 \%$ $(13 / 44)$, and $46.6 \%(54 / 116)$, respectively, and $66.2 \%$ $(43 / 65), 22.7 \%(10 / 44)$, and $31.9 \%(37 / 116)$ in the apparently healthy mucosa, respectively. If patients were divided according to the presence or absence of EBV DNA in their lesions, prevalence rates in the apparently healthy mucosa of patients with EBV-positive vs. EBVnegative lesions were $34 / 48(70.8 \%)$ vs. $9 / 17(52.9 \%), 5 /$ $13(38.5 \%)$ vs. $5 / 31(16.1 \%)$, and $29 / 54(53.7 \%)$ vs. $8 / 62$ $(12.9 \%)$ for OSCC, OL, and OLP patients, respectively. When patients with OLP were divided, the two subgroups showed comparable EBV prevalences, both in the lesion $(45.6 \%, 26 / 57$ in non-EA-OLP; and 47.5\%, 28/59 in EA-OLP) and on the healthy mucosa $(33.3 \%, 19 / 57$ in non-EA-OLP; and 30.5\%, 18/59 in EA-OLP).

\section{Statistical analysis of prevalence data}

The prevalence of EBV in the lesion, as well as on the apparently healthy mucosa, of patients with OSCC, was significantly higher than the prevalence in the controls or in respective samples of the other two groups of patients (Table 1). Regarding only patients with EBV-negative lesions, similar results were found (Table 2). However, when regarding only patients carrying EBV DNA in the lesions, mucosal carriage rates of patients with OSCC and patients with OLP were not significantly different, but were significantly higher than the prevalences of EBV in mucosal controls or in patients with OL (Table 2).

No significant differences were detected in the prevalence of EBV between patients with OL and controls (Table 1). By contrast, patients with OLP carried EBV DNA more frequently than controls in the lesion but not on the healthy mucosa. However, the prevalence of EBV on the apparently healthy mucosa was found to be significantly higher in patients with EBV-positive lesions compared with controls, but not in patients with EBVnegative OLP lesions compared with controls (Table 2).

Comparing patients with the two potentially malignant oral disorders, positivity in the lesion was significantly higher for OLP than for OL. Regarding EBV carriage on the healthy mucosa, OLP and OL patients never differed significantly; neither when comparing the total patient populations, nor when examining patients with EBV-positive or EBV-negative lesions separately (Table 1 and Table 2). The prevalence of EBV in

Table 1

Statistical comparison of Epstein-Barr virus (EBV) prevalence data in different study groups

\begin{tabular}{|c|c|c|c|c|c|c|}
\hline & \multicolumn{3}{|c|}{ Lesion } & \multicolumn{3}{|c|}{ Apparently healthy mucosa } \\
\hline & $\begin{array}{c}\text { OLP } \\
(n=116)\end{array}$ & $\begin{array}{c}\mathrm{OL} \\
(n=44)\end{array}$ & $\begin{array}{c}\text { OSCC } \\
(n=65)\end{array}$ & $\begin{array}{c}\text { OLP } \\
(n=116)\end{array}$ & $\begin{array}{c}\mathrm{OL} \\
(n=44)\end{array}$ & $\begin{array}{c}\text { OSCC } \\
(n=65)\end{array}$ \\
\hline $\begin{array}{l}\text { Controls }(n=68) \\
\text { OLP }(n=116) \\
\text { OL }(n=44)\end{array}$ & $P<0.001$ & $\begin{array}{c}\mathrm{NS} \\
P=0.049\end{array}$ & $\begin{array}{l}P<0.001 \\
P<0.001 \\
P<0.001\end{array}$ & NS & $\begin{array}{l}\text { NS } \\
\text { NS }\end{array}$ & $\begin{array}{l}P<0.001 \\
P<0.001 \\
P<0.001\end{array}$ \\
\hline
\end{tabular}

NS, not significant; OL, oral leukoplakia; OLP, oral lichen planus; OSCC, oral squamous cell cancer.

Table 2

Statistical comparison of Epstein-Barr virus (EBV) prevalences in apparently healthy mucosa

\begin{tabular}{|c|c|c|c|c|c|c|c|}
\hline \multicolumn{4}{|c|}{ Apparently healthy mucosa of EBV-positive patients } & \multicolumn{4}{|c|}{ Apparently healthy mucosa of EBV-negative patients } \\
\hline & OLP $(n=54)$ & OL $(n=13)$ & $\operatorname{OSCC}(n=48)$ & & $\operatorname{OLP}(n=62)$ & OL $(n=31)$ & $\operatorname{OSCC}(n=17)$ \\
\hline $\begin{array}{l}\text { Controls } \\
(n=68)\end{array}$ & $P<0.001$ & NS & $P<0.001$ & Controls $(n=68)$ & NS & NS & $P=0.010$ \\
\hline $\begin{array}{l}\text { OLP } \\
(n=54)\end{array}$ & & NS & NS & OLP $(n=62)$ & & NS & $P=0.001$ \\
\hline $\begin{array}{l}\mathrm{OL} \\
(n=13)\end{array}$ & & & $P=0.050$ & OL $(n=31)$ & & & $P=0.018$ \\
\hline
\end{tabular}

NS, not significant; OL, oral leukoplakia; OLP, oral lichen planus; OSCC, oral squamous cell cancer. 
EA-OLP and non-EA-OLP patients did not differ significantly either in the lesion or on the healthy mucosa; therefore, the two subgroups were not examined in further comparisons.

\section{Immunohistochemistry}

The lymph node sections of the Hodgkin's disease patients (positive control) were consistently strongly 8 positive for EBV, but none of the 48 samples tested, or the lymph nodes from EBV-negative Hodgkin's disease patients, was found to be LMP-1 positive.

\section{Analysis of the association of EBV with clinicopathological data}

Epstein-Barr virus-positive and EBV-negative OSCC patients did not statistically differ in patient characteristics (age, gender) and exposure to risk factors (smoking and alcohol consumption) or clinical data (localization, TN stage, and histological grade of the tumour). The presence of EBV in the lesion or in the apparently healthy mucosa was not found to influence survival, and did not increase the risk of poor outcome.

In the case of patients with OL, younger age (under $55 \mathrm{yr}$ ), but not gender, was a risk factor associated with EBV carriage in the lesion [odds ratio $(\mathrm{OR})=4.09$; $\mathrm{CI}=1.02-16.40 ; P=0.047]$. In patients with OLP, EBV infection appeared more frequently in men than in women $(\mathrm{OR}=2.82 ; \mathrm{CI}=1.17-6.79 ; P=0.02)$, but age was not significantly associated with EBV carriage. Epstein-Barr virus carriage did not influence the risk of unfavourable clinical appearance (EA-OLP).

\section{Discussion}

Data on the aetiological role of EBV in OSCC is controversial. Generally, studies finding a low prevalence of EBV concluded no, or a negligible, aetiological role (14, 17, 18); by contrast, studies reporting a relatively high prevalence of EBV frequently supported an aetio9 logical role $(7,19)$. In some cases, immunohistochemistry has been used to confirm (11) or to reject (14) the possibility of the role of EBV in OSCC. Curiously, most studies concluding an aetiological role of EBV in OSCC were conducted on south-eastern Asian or North African populations with a high prevalence of EBV-associated nasopharyngeal carcinoma $(6,9,10)$.

The prevalence of EBV in our study was high compared with European studies (13) and was comparable to data from studies supporting an aetiological role (9-12), suggesting that EBV may have a role in OSCC in the study population. However, we believe that the high proportion of EBV carriers in our OSCC patients is more likely to be a result of other factors (e.g. tumour-induced B-lymphocyte activation and/or infiltration of the tumour tissue by B cells).

Tumour tissue and apparently healthy mucosa showed almost the same EBV prevalence rate in OSCC patients, which is, to our knowledge, an issue as yet unexamined.
Moreover, even patients with EBV-negative tumours had a notably high carriage rate of EBV on the healthy mucosa (significantly higher than in the oral controls, but comparable to that of patients with EBV-positive tumours). This means that although EBV DNA is present in the majority of the OSCCs, it is prevalent to a comparable 10 degree also on the normal mucosa of OSCC patients. This situation is completely different from that of human papillomaviruses (viruses suspected to occur more strongly in the background of OSCC), in which the carriage of human papillomaviruses on the apparently healthy mucosa of patients with virus-free tumours was almost

11 the same as that in the controls (Szarka et al., in press). In brief, including the healthy mucosa of the patients in the analysis revealed that EBV is not associated with the lesion itself, but rather with OSCC as a disease.

The aetiological role of EBV in OSCC cannot entirely be ruled out, as it is possible that it contributes to car12 cinogenesis, but only in a minority of the tumours, an effect that is not demonstrable as a result of being obscured by the other more important effects in the relatively small populations used in most studies, including 13 the present study. However, the uniform lack of LMP-1 expression in the OSCC tumour cells, found in this study as well as in previous studies in European patients (7), represents another strong argument against the aetiological role.

The high prevalence of EBV DNA in the tumour tissue may be a result of infiltrating $B$ lymphocytes and macrophages infected with EBV and/or to higher susceptibility of the tumour keratinocytes to EBV infection caused by an altered immunological environment arising from the presence of the tumour (14). These factors may, similarly, also increase the prevalence of EBV in the healthy mucosa.

This assumption is supported by the prevalence data in the potentially malignant lesions. In our data set, patients with OLP and OSCC, but not with OL, carried significantly more EBV DNA than controls. Similar data have been reported by SAND et al. (8). The difference between OLP and OL can conveniently be explained by the distinct pathomechanisms of the two diseases: OLP is a disease with a primarily autoimmune pathomechanism (20-22); and OL develops mostly on the background of chronic mechanical or chemical irritation $(23,24)$. It is tempting to speculate that the autoimmune processes lead to an oral environment more favourable for EBV re-activation and shedding, probably provoked and maintained by the altered cytokine profile (25). As immunological changes are present both in OLP and in OSCC, but are not characteristic in OL, this similarity may be the basis of the higher prevalence in both OSCC and OLP.

Data provided in the literature suggest that the role of EBV in OSCC may vary according to geographical regions, for example, in some populations (e.g. Japanese, Chinese, North Africans), EBV may play a role in OSCC $(9,10,26)$; by contrast, in North American and North European populations the role is less probable $(14,15)$. Our data suggest that the Hungarian population belongs to the latter group. 
Notably, those populations in which the aetiological role of EBV in OSCC is more probable are generally the same, where EBV-associated nasopharyngeal carcinoma is prevalent $(6,27)$. This suggests that the genetic and/or habitual factors aiding EBV in the pathogenesis of nasopharyngeal carcinoma may similarly provide an opportunity for EBV to contribute to the development of OSCC in these populations.

Our data draw attention to the fact that high prevalences of EBV in oral lesions compared with controls do not always indicate a true association, and inclusion of the apparently healthy mucosa/tissues into similar studies aid in the correct interpretation of the data.

Acknowledgements - The help of Gyöngyi Seress in sampling patients is gratefully acknowledged. The work was supported by the National Scientific Research Fund (OTKA) F046749 and K73145 grants. The funding sources had no role in study design, data collection, and interpretation or writing of the manuscript.

\section{References}

1. Macsween KF, Crawford D. Epstein-Barr virus - recent advantages. Lancet Infect Dis 2003; 3: 131-140.

2. Slots J, Saygun I, Sabeti M, Kubar A. Epstein-Barr virus in oral diseases. J Periodont Res 2006; 41: 235-244.

3. BornKamm GW, Hammerschmidt W. Molecular virology of Epstein-Barr virus. Philos Trans $R$ Soc Lond B 2001; 356: 437-459.

4. RaAb-Traub N. Epstein-Barr virus in the pathogenesis of NPC. Semin Cancer Biol 2002; 12: 431-441.

5. CoHEN JI. The biology of Epstein-Barr virus: lessons learned from the virus and the host. Curr Opin Immunol 1999; 11: 365-370.

6. Goldenberg D, Golz A, Netzer A, Rosenblatt E, Rachmiel A, Goldenberg RF, JoAchims HZ. Epstein-Barr virus and cancers of the head and neck. Am J Otolaryngol 2001; 22: 197-205.

7. Horiuchi K, Mishima K, Ichijima K, Sugimura M, Ishida T, KIRITA T. Epstein-Barr virus in the proliferative diseases of squamous epithelium in the oral cavity. Oral Surg Oral Med Oral Pathol Oral Radiol Endod 1995; 79: 57-63.

8. Sand LP, Jalouli J, Larsson PA, Hirsch JM. Prevalence of Epstein-Barr virus in oral squamous cell carcinoma, oral lichen planus, and normal mucosa. Oral Surg Oral Med Oral Pathol Oral Radiol Endod 2002; 93: 586-592.

9. Higa M, Kinjo T, Kamiyama K, Imamasa T, Hamada T, IYAmA K. Epstein-Barr virus (EBV) subtype in EBV related oral squamous cell carcinoma in Okinawa, a subtropical island in southern Japan, compared with Kitakyushu and Kumamoto in mainland Japan. J Clin Pathol 2002; 55: 414-423.

10. Higa M, Kinjo T, Kamiyama K, Chinen K, Imasama T, Arasaki A, SunaKawa H. Epstein-Barr virus (EBV)-related oral squamous cell carcinoma in Okinawa, a subtropical island, in southern Japan - simultaneously infected with human papillomavirus (HPV). Oral Oncol 2003; 39: 405-414.
11. Shamaa AA, Zyada MM, Wagner M, Awad SS, Osman MM, Abdel Azeem AA. The significance of Epstein-Barr virus (EBV) and DNA topoisomerase II alpha (DNA-Topo II alpha) immunoreactivity in normal oral mucosa, oral epithelial dysplasia (OED) and oral squamous cell carcinoma (OSCC). Diagn Pathol 2008; 3: 45.

12. Gonzalez-Moles MA, Gutierrez J, Rodriguez MJ, RuizAvila I, Rodriguez-Archilla A. Epstein-Barr virus latent membrane protein-1 (LMP-1) expression in oral squamous cell carcinoma. Laryngoscope 2002; 112: 482-487.

13. Mao EJ, Smith CJ. Detection of Epstein-Barr virus (EBV) DNA by the polymerase chain reaction (PCR) in oral smears from healthy individuals and patients with squamous cell carcinoma. J Oral Pathol Med 1993; 22: 12-17.

14. Cruz I, Van Den Brule A, Brink A, Snijders P, Walboomers J, Van Der WaAl I, Meijer C. No direct role for Epstein-Barr virus in oral carcinogenesis: a study at the DNA, RNA and protein levels. Int J Cancer 2000; 86: 356-361.

15. Goldenberg D, Benoit ne, Begum S, Westra WH, Cohen Y, Koch WM, Sidransky D, Califano JA. Epstein-Barr virus in head and neck cancer assessed by quantitative polymerase chain reaction. Laryngoscope 2004; 114: 1027-1031.

16. Germán P, Beck Z, Semsei I, Kiss S, Görög B, Balogh E, D Tóth F, Nemes Z, PAjor L, Oláh É. Study of pathogenetic role of Epstein-Barr virus in Hungarian patients with B-cell nonHodgkin lymphomas. Orv Hetil 2002; 143: 2619-2624. (Article in Hungarian)

17. Atula S, Auvinen E, Grenman R, Syrjanen S. Human papillomavirus and Epstein-Barr virus in epithelial carcinomas of the head and neck region. Anticancer Res 1997; 17: 44274433.

18. Kobayashi I, Shima K, Saito i, Kiyoshima T, Matsuo K, OzeKi S, OHISHI M, SAKai H. Prevalence of Epstein-Barr virus in oral squamous cell carcinoma. J Pathol 1999; 189: 34-39.

19. Cruz I, Van Den Brule AJ, Steennbergen RD, Snijders PJ, Meijer CJ, Walboomers JM, Snow GB, Van Der Waal I. Prevalence of Epstein-Barr virus in oral squamous cell carcinomas, premalignant lesions and normal mucosa - a study using the polymerase chain reaction. Oral Oncol 1997; 33: $182-188$.

20. Ismail SB, Kumar SKS, Zain RB. Oral lichen planus and lichenoid reactions: etiopathogenesis, diagnosis, management and malignant transformation. J Oral Sci 2007; 49: 89-106.

21. Mithani SK, Mydlarz WK, Grumbine FL, Smith IM, CALIFAno JA. Molecular genetics of premalignant oral lesions. Oral Dis 2007; 13: 126-133.

22. Gonzalez-Moles MA, Scully C, Gil-Montoya JA. Oral lichen planus: controversies surrounding malignant transformation. Oral Dis 2008; 14: 229-243.

23. Neville BW, Day TA. Oral cancer and precancerous lesions. CA Cancer J Clin 2002; 52: 195-215.

24. NAPIER SS, SPEIGHT PM. Natural history of potentially malignant oral lesions and conditions: an overview of the literature. J Oral Pathol Med 2008; 37: 1-10.

25. De Sousa FA, Rosa LE. Oral lichen planus: clinical and histopathological considerations. Rev Bras Otorrinolaringol 2008; 74: 284-292.

26. Van Rensburg EJ, Engelbrecht S, Van Heerden W, RAubenheimer E, Schoub BD. Detection of EBV DNA in oral squamous cell carcinomas in a black African population sample. In Vivo 1995; 9: 199-202.

27. CraWford DH. Biology and disease associations of EpsteinBarr virus. Philos Trans R Soc Lond B 2001; 356: 461-473. 


\section{Author Query Form}

\section{Journal: $\quad$ EOS}

\section{Article: $\quad 660$}

Dear Author,

During the copy-editing of your paper, the following queries arose. Please respond to these by marking up your proofs with the necessary changes/additions. Please write your answers on the query sheet if there is insufficient space on the page proofs. Please write clearly and follow the conventions shown on the attached corrections sheet. If returning the proof by fax do not write too close to the paper's edge. Please remember that illegible mark-ups may delay publication.

Many thanks for your assistance.

\begin{tabular}{|c|c|c|}
\hline $\begin{array}{l}\text { Query } \\
\text { reference }\end{array}$ & Query & Remarks \\
\hline 1 & $\begin{array}{l}\text { AUTHOR: 'in' has been inserted in the article title. Please check that } \\
\text { the intended meaning has not been changed. }\end{array}$ & \\
\hline 2 & AUTHOR: Please explain what you mean by ' the normal population'. & \\
\hline 3 & $\begin{array}{l}\text { AUTHOR: ' referring to the Faculty of Dentistry for regular oral } \\
\text { screening' has been rewritten. Please check/approve the changes. }\end{array}$ & \\
\hline 4 & $\begin{array}{l}\text { AUTHOR: 'patient' has been inserted. Please check that the intended } \\
\text { meaning has not been changed. }\end{array}$ & \\
\hline 5 & $\begin{array}{l}\text { AUTHOR: commas have been placed before 'according' and after 'cells' } \\
\text { in the phrase ', according to the manufacturer's recommendations for } \\
\text { tumour tissue samples and exfoliated cells,'. Please check that the } \\
\text { intended meaning of the sentence has not been changed. }\end{array}$ & \\
\hline 6 & $\begin{array}{l}\text { AUTHOR: 'Due to the low case number of non-homogeneous OL' has } \\
\text { been rewritten. Please check/approve the changes. }\end{array}$ & \\
\hline 7 & AUTHOR: Please define 'TN'. & \\
\hline 8 & AUTHOR: ' for EBV' has been inserted. Please check/approve. & \\
\hline 9 & $\begin{array}{l}\text { AUTHOR: 'contrastingly, studies reporting relatively high prevalence } \\
\text { frequently supported it' has been rewritten. Please check/approve. }\end{array}$ & \\
\hline 10 & $\begin{array}{l}\text { AUTHOR: The text 'it is comparably prevalent on the normal mucosa } \\
\text { of OSCC patients as well.' has been rewritten. }\end{array}$ & \\
\hline 11 & $\begin{array}{l}\text { AUTHOR: Szarka et al., in press has not been included in the } \\
\text { Reference list. Please provide full publication details. }\end{array}$ & \\
\hline 12 & AUTHOR: 'but' has been inserted. Please check/approve. & \\
\hline 13 & $\begin{array}{l}\text { Auhor: The text 'which effect remain indemonstrable due to being } \\
\text { obscured by the other more important effects in the relatively small } \\
\text { populations used in most studies including the present.' has been } \\
\text { rewritten. Please check/approve the changes. }\end{array}$ & \\
\hline
\end{tabular}




\section{Please correct and return this set}

Please use the proof correction marks shown below for all alterations and corrections. If you wish to return your proof by fax you should ensure that all amendments are written clearly in dark ink and are made well within the page margins.

\begin{tabular}{|c|c|c|}
\hline Instruction to printer & Textual mark & Marginal mark \\
\hline Leave unchanged & ... under matter to remain & ( ) \\
\hline $\begin{array}{l}\text { Insert in text the matter } \\
\text { indicated in the margin }\end{array}$ & $h$ & $\begin{array}{l}\text { New matter followed by } \\
h \text { or } h \otimes\end{array}$ \\
\hline Delete & $\begin{array}{l}\text { I through single character, rule or underline } \\
\text { or }\end{array}$ & $\sigma$ or $\sigma(x)$ \\
\hline $\begin{array}{l}\text { Substitute character or } \\
\text { substitute part of one or } \\
\text { more word(s) }\end{array}$ & I through letter or & $\begin{array}{l}\text { new character / or } \\
\text { new characters / }\end{array}$ \\
\hline Change to italics & — under matter to be changed & $\leftarrow$ \\
\hline Change to capitals & $\equiv$ under matter to be changed & $\equiv$ \\
\hline Change to small capitals & $=$ under matter to be changed & $=$ \\
\hline Change to bold type & $\sim$ under matter to be changed & $\sim$ \\
\hline Change to bold italic & $\bar{\sim}$ under matter to be changed & $\underline{s i n}$ \\
\hline Change to lower case & Encircle matter to be changed & $\Rightarrow$ \\
\hline Change italic to upright type & (As above) & \\
\hline Change bold to non-bold type & (As above) & \\
\hline Insert 'superior' character & $\begin{array}{l}/ \text { through character or } \\
K \text { where required }\end{array}$ & $\begin{array}{l}y^{\prime} \text { or } y \\
\text { under character } \\
\text { e.g. } y^{2} \text { or } y^{2}\end{array}$ \\
\hline Insert 'inferior' character & (As above) & $\begin{array}{l}\lambda \\
\text { over character } \\
\text { e.g. } \hat{\Sigma}\end{array}$ \\
\hline Insert full stop & (As above) & $\odot$ \\
\hline Insert comma & (As above) & , \\
\hline Insert single quotation marks & (As above) & $\begin{array}{l}\dot{y} \text { or } \dot{x} \text { and/or } \\
\dot{y} \text { or } \dot{y}\end{array}$ \\
\hline Insert double quotation marks & (As above) & $\begin{array}{l}\ddot{y} \text { or } \ddot{y} \text { and/or } \\
\ddot{y} \text { or } \ddot{y}\end{array}$ \\
\hline Insert hyphen & (As above) & 1 \\
\hline Start new paragraph & 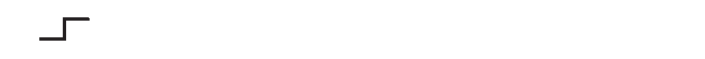 & 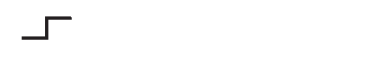 \\
\hline No new paragraph & $\infty$ & $\omega$ \\
\hline Transpose & $\sqcup$ & $\sqcup$ \\
\hline Close up & linking $\bigcirc$ characters & \\
\hline $\begin{array}{l}\text { Insert or substitute space } \\
\text { between characters or words }\end{array}$ & $\begin{array}{l}\text { I through character or } \\
\Lambda \text { where required }\end{array}$ & \\
\hline $\begin{array}{l}\text { Reduce space between } \\
\text { characters or words }\end{array}$ & $\begin{array}{l}\text { between characters or } \\
\text { words affected }\end{array}$ & $\uparrow$ \\
\hline
\end{tabular}

